\title{
The Relationship between Learning Motivation and Paragraph Knowledge on the Students' Ability to Write a Short Story at SMPN 21 Padang
}

\author{
Yulia Pebriani \\ Indonesian Languange And Literature Indonesian Departement Education \\ STKIP PGRI West Sumatera \\ West Sumatera, Indonesia \\ yuliafebriani.yf@gmail.com
}

\begin{abstract}
Write to assemble said to be a paragraph. Writing by using the paragraph correct will make readers can follow the idea of mind and the author. This way, it can be known from write short stories one of them. Writing short stories can serve as a means to pour out feelings, experiences, and ideas. For that, in learning to write short stories students are required to develop their creativity by making an idea that will be a topic for short stories. Them come from imagination, personal experience, or the experience of others. So with the motivation to learn with the knowledge of paragraphs is important for writers in developing ideas, ideas in the skills of writing short stories. One improves the learning process and quality of learning in schools through the knowledge of the students' knowledge of the paragraphs and motivations. Learning not based on a teacher, but on the students. With learning to write short stories can improve the process of student creativity generated through effective learning. Based on the research results can be concluded. First, the results of the calculation of the level of understanding of learning motivation variabes by $70 \%$, while the relationship of learning motivation to influence students' writing skill of 23.48\%. Second, the result of the level of understanding of the respondents to the paragraph knowledge variable is $71.23 \%$. Third, the calculation of the level of understanding of the respondents to the variable of short story writing skills is $80 \%$ by cont ributing to learning motivation and paragraph knowledge.
\end{abstract}

Keywords: learning motivation, paragraph knowledge, writing short story

\section{INTRODUCTION}

Writing, one of the aspects of language skills, is important for students to master, especially in the learning of Indonesian Language and Literature at junior / MTs level. One type of writing skill demanded in the content of Education Unit Level Curriculum Level (KTSP) in 2006 for junior high school / MTs for Indonesian Language and Literature is the skill of writing short stories. The learning of short story writing is on the subjects of Indonesian Language and Literature at SMP / MTs Class IX Semester I, Competency Standard (SK) 8, which reads, "Reveal thoughts of feeling, and experience in short stories". This competency standard consists of two Basic Competencies. This study focused on the 2nd KD, which is "Writing a short story based on the event experienced". The competency standard of Indonesian Language and Literature Course SMP class IX for writing requires students to express their thoughts, feelings, and experiences in writing short stories. That is, in addition to students are expected to master the material presented teachers, students are also able to express thoughts, ideas, opinions, and feelings through the skills of writing literature. In this case, the intended skill is a short story writing skill.

Writing short stories can serve as a means to pour out feelings, experiences, and ideas. For that, in learning to write short stories students are required to develop their creativity by making an idea that will be a topic for short stories. They come from imagination, personal experience, or the experience of others. Students are also required to be able to develop the idea of being as a coherent and coherent form of essay.

Short story writing is done through a process approach. According to Endaswara (2005: 163) the approach of the process is expected (a) does not appear short stories of tricks, (b) does not cause the subjects to be reluctant and afraid to write short stories, (c) will not be repeated anxiety in teen short story writing contest for students but participants precisely adult and senior authors, (d) subjects will be fond, motivated, motivated and productive to create short stories. According to Rhodesl (in Endaswara, 2005: 169) added that the creative process of creating short stories can be pursued through the following four stages. First, the preparation stage is the stage of idea generation. This stage begins with the appearance of the data. Data comes from the experience itself or from outside yourself. The more rich the experience, the more students are ready to enter the next stage of the process. Second, the incubation stage is the stage of maturation and pengelohan ideas or people often call it by "incubation" ideas. Third, the stage of illumination is mengungakapkan ideas, by enriching the vocabulary of students by providing literature reading. Fourth, the stage of verification is to stimulate the creativity of students by comparing the existing short stories.

In line with the opinion, Aminuddin, (1993: 2) explains that the process approach in the context of short story learning, namely (1) the learning outcomes of the subjects must be pursued through the articulation of the reality of learning targets, (2) if the reality is able to generate interest, curiosity and (3) the understanding of a potential reality can be formulated by the subject in line with the recognition and appreciation of the reality that the target of study and konsespsi difficult to understand, (4) 
understanding obtained by the subject can grow sustainably, and ( 5) the learning process of the subjects is directed based on the adaptation of the environment.

With regard to the importance of short story writing skills as described above, short story writing skills should be trained from the beginning in educational institutions, especially high schools such as junior and senior high schools. Students should be able to understand and master short story writing skills. But the phenomena that occur in the field noticed that the skills of writing short stories of students is still low. Another factor that plays an important role in developing ketremapilan writes short stories by extending paragraph knowledge. The knowledge of the paragraph is very important in developing the mindset and ideas and ideas in addition to the knowledge of sentence structure. Knowledge of paragraphs will guide students to be able to pour ideas and develop appropriately in written form.

\section{METHOD}

This type of research is quantitative research. Procedures in data processing research conducted in this study is required to use the numbers. The numbers in this study are the score and questionnaire value of student learning motivation as well as the score and the value of the test results of writing short stories students SMP N 21 Padang. The research method applied is correlation method. Correlation method aims to describe, analyze, and interpret data in the form of numbers and find whether or not the relationship between variables with each other.

The correlation used in this research is cause-effect correlation. In accordance with the opinion of Arikunto (2010: 76), causeeffect correlation concerns such as research on discipline with learning achievement, attention of parents with the level of juvenile delinquency, reading interest with language skills, and so forth. The dependent variable is the short story writing skill and the moderator variable used in this research is learning motivation and paragraph knowledge.

This study uses two instruments. First a questionnaire of learning motivation, Second a questionnaire of paragraph knowledge. Questionnaire in learning to write short story, (3) Patience in learning to write short story, (4) Enthusiasm in learning to write short story, (5) Responsibility in learning writing short stories, (6) The existence of awards in learning to write short stories, (7) The existence of a learning environment to write short stories. Questionnaires of paragraphs are organized on the basis of three indicators (1) knowledge of good paragraph criteria. (2) knowledge of the elements that build a good paragraph. (3) knowledge of the proper use of language in a paragraph. Second, the performance test. The test is given after the students get treatment.

Data analysis of the results of this study using statistical methods to see the results of student success in learning. Data were analyzed using the average equality test. This average equality test has normality and homogeneity requirements, then first tested normality and homogeneity test. According to Sudjana (2005: 466-467), for normality test using liliefors test and for homogeneity test used F test. Based on normality and homogeneity test results can be known normal distributed data and derived from homogeneous variance. Therefore, to test the hypothesis of the result of short story writing skill (Hypotheses 1,2 , and 3 ) is done by using $\mathrm{t}$ test because the data obtained are normally distributed and derived from homogen variance.

\section{A. The Result of Student's Ability of Writing Short Story Writing}

\section{FINDING AND DISCUSSION}

Based on the results of the analysis conducted on the test results of the students' writing short stories on the experimental class and control classes are as follows.

\section{Title}

The average that students get on short story writing skills for the title indicator is 3.65. Students who are at the fifth level of performance is if the title of the students according to the theme, short and interesting as much as 2 people. Students who are at the fourth level of work is when the title of students short stories according to the theme, not too long but attracted as many as 14 people. Students who get are at third level of performance that is if the title according to theme, short but not interesting as much as 5 people, and student who is at second level of performance that is if title of student short story irrelevant with theme determined and too long and not interesting as much 2 person .

\section{Plot}

The average students acquired on the skill writing skill for the flow indicator of 3.84. Student's at a level of performance one that is when students are able to narrate the story line from the introduction of the story situation to solving the problem, and show the causal relationship as much as one person. Students who are in the fourth level of performance that is if the students are able to narrate the storyline from the introduction of the story situation to solving the problem, but does not show the causal relationship as many as 17 people, while students who are at the third level of performance that is when students are able to narrate the story line starting from affirmation of the situation until the emergence of problems as many as eight people.

\section{Background}

The average that students get on short story writing skills for background indicators is 4.16. Students who are at the fifth level of performance that is if students are able to describe the background place, atmosphere and time in the story sebanayak 2 people. Students who are at the fourth level of performance is when students are able to describe the background place and atmosphere in 
the story as many as 22 people. Students who are in the third performance is when students are able to describe the background of the place, and the character in the story as much as 2 people.

\section{Language (Diction, Spelling, and Style)}

The average that students get on the short story writing short for the indicator of 3,88 . Students who are in the performance of five that there are the number of mistakes of writing 1-3, spelling mistakes 1-5 and language style presented more than 6 as much as one person. Students who are in the fourth performance that is the number of misconduct 4-6 words, spelling errors 6-10 and style of language presented more than 5-6 as many as 20 people. Students who are at the third level of performance that is the number of 7-9 word-writing errors, spelling errors of 11-15 and language style presented more than 3-4 as many as 12 people.

\section{B. The Relationship Motivation Learning on Writing Ability Short story}

The partial correlation $(\mathrm{R})$ is 0.378 with the direction of the positive relationship (+). That is, the higher the value of student's learning motivation, the higher the students' short story skills. This relationship can be seen the hypothesis obtained tcount 3.581> from ttabel 1.680. The magnitude of coefficient of determination $\mathrm{R} 2=0.253$ or this of all independent variables, learning motivation affects students' short story writing skills by $23.48 \%$, while others are influenced by other variables.

Based on the above description, it can be concluded that the higher the students 'learning motivation, the higher the students' writing skill. Conversely, the lower the motivation to learn students, the lower the skills of writing short stories of students. The relationship between short story writing skills and learning motivation is a positive relationship. It can be dilihar that students have a special time to learn as well as the motivation to learn and there is encouragement from within students to learn. This is in accordance with the opinion of Suhana and Hanafiah (2012: 26) added that the motivation to learn is the power (power motivation), the driving force (driving force), or tool builders willingness and strong desire in learners to learn actively, creatively, effective, innovative, and fun in order to change behavior, both in cognitive, affective, and psychomotor aspects.

In the process of learning to develop the skills of short story writing motivation to learn plays an important role in providing passion, enthusiasm, and a sense of calm in learning so that a highly motivated have a lot of energy to carry out learning activities. Sardiman (2006: 83) generally put forward the general characteristics of motivation as follows. First, persistent in the task (can work continuously for a long time, never stop before finish Second, resilient to face difficulty (no despair) No need for outside encouragement to perform as best as possible (not quickly satisfied with achievement he has achieved.) Third, showing interest in various issues for adults. Fourth, prefer to work independently, Fifth, get bored with routine tasks. Sixth, can defend his opinion. Seventh, it is not easy to let go of what is believed Eighth, happy to find and solve problems.

\section{The Relationship Paragraph Knowledge on Writing Ability Short Story}

Partial correlation $(\mathrm{R})$ ie equal to 0.461 with the direction of positive relationship (+). That is, the higher the value of paragraph knowledge that students have, the higher the students' short story skills. This relationship can be seen hypothesis obtained titung 4.753> from ttabel 1.680. The magnitude of the determination coefficient $\mathrm{R} 2=0.253$ or this of all independent variables, the knowledge of paragraphs affects the skill of writing short stories of students by $25.67 \%$, while others are influenced by other variables.

Based on the above description, it can be concluded that the higher the knowledge paagraf owned by students, the higher the students' writing skills. Conversely, the lower the knowledge of the paragraphs of students, the lower the skills of writing short stories of students. The relationship between writing short stories and paragraph knowledge is a positive one. In the process of learning by reproducing repetitive material on paragraphs in terms of writing and development patterns so that in the process of writing, students are able to develop paragraphs clearly and precisely. Tarigan (2008: 38) reveals good paragraph requirements when paragraphs are written in good and correct language. A good language is a language that does not violate the rules set by the language user community.

\section{Relationship Between Motivation Learning With Paragraph Knowledge of Short Story Writing Skills}

Partial correlation (R) ie equal to 0.631 with the direction of positive relationship (+). That is, the higher the value of paragraph knowledge and learning motivation that students have, the higher the students' short story skills. The magnitude of the determination coefficient R2 $=0.253$ or this of all independent variables, the knowledge of paragraphs and the motivation of students 'learning affects students' short story writing skills of $32.50 \%$.

In accordance with the above explanation, it can be said that the knowledge of paragraphs and motivation of learning relate to short story writing skills. This ability can be obtained by intensive training. Likewise with writing skills. Writing ability is not a hereditary skill, but it is the result of learning and practice perseverance. This ability is closely related to the ability to read. Good writers, usually also diligent readers. The skill of applying Enhanced Spelling, choosing the right words, making effective sentences have not fully guaranteed a person can write well. In pouring ideas / thoughts, a writer is required to connect the sentence with sentences in a unified whole. The relationship expresses the unity that is bound by the structure of language and logical unity. In writing or writing-writing, the bond is born in the form of a paragraph. Paragraphs are at the core of the pouring of thoughts which are supported by all sentences in the paragraph, from the sentence of the sentence, the main sentence or the topic sentence, the explanatory sentence to the closing sentence. This set of sentences is interconnected in a series to form an idea. 
In addition, students' short story writing skills, not influenced by paragraph knowledge, but learning motivation can also affect the learning process of short story writing. learning motivation is an internal and external impulse to learners who are learning to make behavioral changes, generally with some supportive indicators or elements. It has a big role in one's success in learning. Indicators of motivation to learn can be classified as follows: the desire and desire succeed, the encouragement and needs in learning, the expectation and future aspirations, the awards in learning, the activities of interest in learning, the existence of a conducive learning environment.

\section{CONCLUSION}

Based on the research results can be concluded. First, the results of the calculation of the level of understanding of learning motivation variables by $70 \%$, while the relationship of learning motivation to influence students' writing skill of $23.48 \%$. Arinya, motivation to learn that a person (students) to provide all the power (conditions) to learn so he wants or want to do the learning process. Without motivation will not be possible to learn. So, his attention will be more intensive with the motivation in a person to study the subject matter so that a student is interested in the subject matter. Second, the result of the level of understanding of the respondents to the paragraph knowledge variable is $71.23 \%$. That is, a good paragraph is a unity of paragraphs. the unity of the paragraph is when each pargaraf contains only one main idea embodied in the main sentence. If in a paragraph there are more than one main idea, then the discussion in the main idea of the paragraph is not focused on what to say. So the collection of sentences is not a good paragraph. Third, the calculation of the level of understanding of the respondents to the variable of short story writing skills is $80 \%$ by contributing to learning motivation and paragraph knowledge.

\section{References}

Atmazaki. (2005). Kiat-Kiat Mengarang dan Menyunting. Padang: Budaya Citra. Aminuddin. (2011). Pengantar Apresiasi Sastra. Bandung: Sinar Baru AlgensindSo.

Arikunto, Suharsimi. (2012). Prosedur Penelitian Suatu Pendekatan Praktek. Jakarta: Rineka Cipta

Emzir. (2009). Metodologi Penelitian Pendidikan: Kuantitatif dan Kualitatif. Jakarta: PT Raja Grafindo Persada

Endraswara, Suwardi. (2005). Metode dan Pengajaran Sastra. Yogyakarta: Buana Pustaka.

Ferguson, G. A. (1976). Statistical Analisysis in Psychology and Education International Student Edition. Tokyo: McGraw-Hill Kogakusha.

Hasanuddin, WS dan Muhardi. (2006). Prosedur Analisis Fiksi: Kajian Strukturalisme. Padang: Yayasan Citra Budaya Indonesia. Hernacki Mike, Deporter Bobbi. (2002). Quantum Learning. Bandung: Kaifa.

Irianto, Agus. (2004). Statistika Konsep Dasar dan Aplikasinya. Jakarta: Perdana Media.

Priyatni, Endah Tri. (2010): Membaca Sastra dengan Ancangan Literasi Kritis. Jakarta. Bumi Aksara.

Suhana, dan Hanafiah. (2012). Konsep Strategi Pembelajaran. Bandung: Refika Aditama.

Sutikno, dan Fathurrohman. (2007). Strategi Belajar Mengajar. Bandung: PT Refika Aditama.

Tarigan, Henry Guntur. (2008). Menulis: Sebagai Suatu Keterampilan Berbahasa (Edisi Revisi). Bandung: Angkasa. 